International Journal of Current Advanced Research

ISSN: O: 2319-6475, ISSN: P: 2319 - 6505, Impact Factor: SJIF: 5.995

Available Online at www.journalijcar.org

Volume 6; Issue 3; March 2017; Page No. 2366-2371

DOI: http://dx.doi.org/10.24327/ijcar.2017.2371.0011

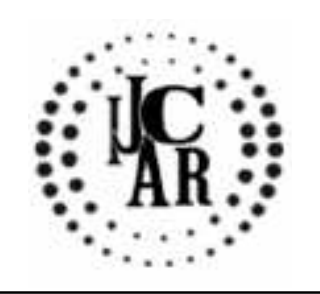

Research Article

\title{
MICRONUCLEI IN EXFOLIATED BUCCAL CELLS: A BIOMARKER FOR DNA DAMAGE LEADING TO PROGRESSION OF LATE DIABETIC COMPLICATIONS IN TYPE 2 DIABETES MELLITUS PATIENTS
}

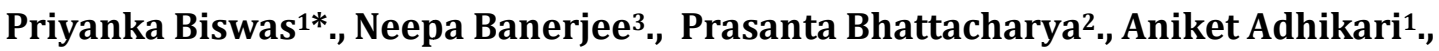 Shankarashis Mukherjee ${ }^{3}$ and Madhusnata De ${ }^{1}$}

\author{
${ }^{1}$ Department of Genetics, Vivekananda Institute of Medical Sciences, Ramakrishna Mission Seva Pratishthan, \\ Kolkata- 700026 \\ 2Department of Surgery, Ramakrishna Mission Seva Pratishthan, Vivekananda Institute of Medical Sciences, \\ 99 Sarat Bose Road, Kolkata-700026 \\ ${ }^{3}$ Department of Physiology, University of Calcutta
}

\begin{tabular}{|c|}
\hline A R T I C L E \\
\hline Article History: \\
\hline $\begin{array}{l}\text { Received } 6^{\text {th }} \text { December, } 2016 \\
\text { Received in revised form } 19^{\text {th }} \text { January, } 2017 \\
\text { Accepted } 9^{\text {th }} \text { February, } 2017 \\
\text { Published online } 28^{\text {th }} \text { March, } 2017\end{array}$ \\
\hline
\end{tabular}

Key words:

Type 2 Diabetes Mellitus; Micronuclei; Oxidative stress; DNA damage; Genomic instability.

\begin{abstract}
A B S T R A C T
Elevated levels of DNA damage, decreased efficacy of DNA repair and high susceptibility to mutagens have been associated with type 2 diabetes mellitus. Micronuclei (MN) are a sensitive indicator of genetic damage and a marker of DNA damage. MN is also a morphological marker of chromosomal instability. So the presence of MN in cells reflects structural chromosomal aberrations arising during mitosis. Our aim was to evaluate the frequencies of micronuclei, as a biomarker for DNA damage, in Giemsa stained buccal cells of T2DM patients and healthy controls. A case-control study of seventy six patients with T2DM and twenty five control group participants were recruited from different areas of West Bengal for determination of frequency of MN. All procedures were done with the informed consent of participants. In the present study, frequency of MN found in T2DM patients was $4.08 \pm 3.77$, which was much higher than the control group participants $(1.1 \pm 0.9)$. Frequency of MN increased due to the elevated level of DNA damage in these patients than the controls. Hence, in the present study, increased DNA damage may be due to increased oxidative stress leading to genomic instability, which in turn may lead to the progression of T2DM and its complications and contribute to an increased risk for cancer. This depicts that MN may be a useful constituent in a panel of biomarkers for the risk of late diabetic complications and can be a predisposing factor for development of cancer.
\end{abstract}

Copyright $\odot 2017$ Priyanka Biswas et al. This is an open access article distributed under the Creative Commons Attribution License, which permits unrestricted use, distribution, and reproduction in any medium, provided the original work is properly cited.

\section{INTRODUCTION}

Type 2 diabetes mellitus (T2DM), the most frequent subtype of diabetes, comprises a complex heterogeneous group of metabolic diseases characterized by high levels of blood glucose (hyperglycaemia) and impaired insulin action and/or insulin secretion.The number of people with T2DM is increasing in every country with $80 \%$ of population with DM living in low- and middle-income countries [1]. It is estimated that T2DM affects about 150 million people worldwide and it is expected to rise to about 439 million people by the year $2030[2,3]$.

India ranked first in the world for the prevalence of the disease, followed by China and USA [4].There are currently

*Corresponding author: Priyanka Biswas

Department of Genetics, Vivekananda Institute of Medical

Sciences, Ramakrishna Mission Seva Pratishthan,

Kolkata- 700026 approximately 40.9 million patients suffering from diabetes mellitus in India and it is expected to rise to about 69.9 million by the year 2025 [5]. Anticipating an epidemic like increase in the number of diabetic patients, India is being referred to as the diabetic capital of the world [6]. About $31.0 \%$ populations of West Bengal are suffering from T2DM [7]. The incidence of T2DM varies substantially from one geographical region to the other as a result of environmental and lifestyle risk factors [2]. One of the factors associated with diabetic complications is the process of non-enzymatic glycation of proteins, lipids and nucleic acids, with subsequent formation of advanced glycation end products (AGEs) [8]. One of the main consequences of this adverse action is the formation of oxidative stress (OS). Formation of glycation end products leads to OS and subsequent DNA damage via the oxidation of DNA bases and sugar-phosphate binding sites. Increasing evidence in both experimental and clinical studies suggest OS plays a major role in the pathogenesis of both types of diabetes mellitus. OS represents 
an imbalance between the production and manifestation of reactive oxygen species (ROS) especially free radicals and a biological system's ability to detoxify the reactive intermediates or to repair the resulting damage. OS induces cellular damage and insulin resistance, and emerges as the major mechanisms for related co-morbidities [9, 10, 11]. Previous reports investigated the fact that ROS, that includes $\mathrm{O} 2-, \mathrm{OH} \bullet$, and $\mathrm{H} 2 \mathrm{O} 2$, are highly reactive and capable of damaging cellular macromolecules, including proteins, lipids and DNA [12]. Because of the hyperglycemia and free radicals, T2DM has been associated with elevated levels of DNA damage, increased susceptibility to mutagenic effects and/or DNA replication arrest and reduction in efficacy of DNA repair that causes genomic instability and a risk for developing cancer [13,14].

Micronuclei (MN) is a sensitive indicator of genetic damage and a marker of DNA damage. MN is also a morphological marker of chromosomal instability. $\mathrm{MN}$ is a condensed form of chromatin with the appearance of small nuclei present in the cytoplasm, usually about $1 / 16$ to $1 / 3$ of the mean diameter of the main nuclei. They are round or oval, non-refractile structures seen adjacent to or touching the main nucleus but they are never seen connecting to or overlapping with the main nucleus [15]. It is formed from acentric chromosome/chromatid fragments that got segregated from the spindle during anaphase stage of cell division, displaced, enclosed by a nuclear membrane [16]. Acentric chromosome and chromatid fragments are formed when there is a defect in the DNA repair mechanism or if there exists DNA damage that exceeds repair capacity. Whole chromosomes get malsegregated as $\mathrm{MN}$ when there are defective kinetochore proteins that help in assembly of mitotic spindle due to cytosine and histone hypomethylation. Mitosis check point defect and abnormal centromere amplification are other causes for whole chromosome malsegregation [17]. MN can be observed in normal individuals, but in insignificant numbers. Significant increase in $\mathrm{MN}$ is known to be found in individuals exposed to environmental toxins, biohazard substance, radiation, drugs, and in diseases including chronic inflammatory conditions, cancers and genetic syndromes. So the presence of $\mathrm{MN}$ in cells reflects structural aberrations arising during mitosis, thus it can be used as a diagnostic marker for cancer screening [18]. Elisabeth mullner et al. stated that there is a 2-fold increase in the frequency of buccal $\mathrm{MN}$ in diabetic individuals than in nondiabetic participants [18]. $\mathrm{MN}$ in exfoliated buccal cells are a novel and noninvasive biomarker of genomic stability, formed during mitosis and represent the loss of a whole chromosome or chromosome fragments that failed to be incorporated in the main nuclei.

Genomic instability is a hallmark of tumourigenesis $[19,20]$. Shettigar et al investigated that MN levels in diabetic patients are correlated with glycosylated hemoglobin levels. They were able to positively correlate both the readings and suggested that $\mathrm{MN}$ index can be used as a biomarker to predict the occurrence of diabetic complications [11]. Martinez-Pérez L et al. illustrated that T2DM patients have significantly more genetic damage (in terms of $\mathrm{MN}$ frequency) than healthy controls. Hence it can be stated that MN may be a useful constituent in a panel of biomarkers for the risk of diabetes and its complications [16]. Few studies have investigated DNA damage by MN in patients with type 2 diabetes, and these studies have shown increased frequency of micronuclei in diabetic patients $[16,21]$. It is worth mentioning that the authors themselves highlighted the need to conduct further studies to validate this investigation. Most importantly, no study was found in the literature which sought to investigate the MN frequency in the context of type 2 diabetes in population of West Bengal. We hypothesise that the presence of T2DM could proportionally account the increase in DNA damage. Therefore, we aimed to evaluate the frequencies of micronuclei, as a biomarker for DNA damage, in Giemsa stained buccal cells of T2DM patients and healthy controls.

\section{MATERIALS AND METHODS}

\section{Study setting and subjects}

A total of seventy six patients with T2DM and twenty five healthy control subjects were recruited from different areas of West Bengal. The participants were age and sex matched. The patients were confirmed of having T2DM by impaired fasting glucose test $(>126 \mathrm{mg} / \mathrm{dl})$ and oral glucose tolerance test $(>200 \mathrm{mg} / \mathrm{dl})$. The controls had a self reported history of having normal glucose metabolism. Detailed personal histories were collected from the participants with the help of questionnaire. All procedures were done with the informed consent of participants. We had excluded the patients who had fever, acute and chronic infections, malignancy, acute and chronic nephritis, cirrhosis, and congestive heart failure. All the patients were under stable conditions during assessment.

\section{Collection of buccal mucosal cells and Giemsa staining}

The participants were asked to wash their mouth with $0.9 \%$ saline. Then the inner sides of the cheeks were scrapped using a sterile spatula to obtain oral mucosa containing exfoliated buccal epithelial cells. The cells were smeared on clean glass slides. For each subject, triplicate slides of buccal cells were made and Giemsa staining was performed according to the procedure of Tolbert et al [22]. About 1000 cells were screened under the compound light microscope from each participant. Obtained data were analyzed and compared.

\section{RESULTS}

The clinical characteristics of the study participants are listed in Table 1. The mean age of theT2DM patients was $50.4 \pm 18$.1years ranging between 34 - 76 years, with a mean duration of the diabetes of $8.4 \pm 8.1$ years (range: $1-25$ years). Forty five patients $(60 \%)$ had a family history of T2DM in our study. Diabetic individuals had higher BMI (body mass index) than the controls.

Impaired fasting glucose, Oral glucose tolerance test and HbA1C were significantly higher in T2DM patients than the control group participants. The study participants included both men and women and the clinical characteristics incorporated personal history of education, smoking, addiction of alcohol, betel quid or antioxidant supplement consumption, or the practice of exercise. All the study participants were from Bengalee culture. Socioeconomic status, particularly income and educational qualification are important factors in higher prevalence of T2DM.Diabetes 
may be up to two times more prevalent in low income populations compared to wealthy populations $[23,24,25]$.

Table I General characteristics of the study participants

\begin{tabular}{|c|c|c|c|}
\hline \multirow{2}{*}{\multicolumn{2}{|c|}{ Criteria }} & \multicolumn{2}{|c|}{ Groups } \\
\hline & & Controls $(n=25)$ & $\begin{array}{c}\text { T2DM patients } \\
(\mathrm{n}=76)\end{array}$ \\
\hline \multirow{2}{*}{ Gender } & Male & $17(68 \%)$ & $54(71 \%)$ \\
\hline & Female & $8(32 \%)$ & $22(29 \%)$ \\
\hline \multicolumn{2}{|l|}{ Age (years) } & $54.6 \pm 21.6$ & $50.4 \pm 18.1$ \\
\hline \multicolumn{2}{|c|}{ Duration of diabetes (years) } & - & $8.4 \pm 8.1$ \\
\hline \multicolumn{2}{|c|}{$\mathrm{BMI}\left(\mathrm{kg} / \mathrm{m}^{2}\right)$} & $23.4 \pm 3.89$ & $30.9 \pm 3.62$ \\
\hline \multirow{3}{*}{$\begin{array}{l}\text { Family History of } \\
\text { T2DM } \\
\text { (no. of cases) }\end{array}$} & Present & +5 & 45 \\
\hline & Absent & & 31 \\
\hline & Tobacco & $5(20 \%)$ & $9(11.25 \%)$ \\
\hline \multirow{3}{*}{$\begin{array}{l}\text { Addiction } \\
\text { (no. of cases) } \\
\text { Habit(Exercise) } \\
\text { (no. of cases) }\end{array}$} & Alcohol & $3(12 \%)$ & $2(2.5 \%)$ \\
\hline & Betel Quid & $2(8 \%)$ & $3(3.75 \%)$ \\
\hline & & 7 & 5 \\
\hline \multirow{3}{*}{$\begin{array}{l}\text { Education } \\
\text { (no. of cases) }\end{array}$} & None & $6(24 \%)$ & $2(2.5 \%)$ \\
\hline & Elementary & $13(52 \%)$ & $48(62.5 \%)$ \\
\hline & Bachelor & $6(24 \%)$ & $26(35 \%)$ \\
\hline \multicolumn{2}{|c|}{ Antioxidant Supplementation } & $5 \%$ & $2 \%$ \\
\hline
\end{tabular}

[N.B: (Mean \pm SD; unless otherwise specified); BMI: body mass index.]

In the present study, most of the patients with T2DM came from lower economic condition and had elementary education, presented in Figure 1. Hence, individuals with lower income were at higher risk for T2DM. Our findings also support the previous studies showing association between income and the prevalence of T2DM, implying that higher income is an indicator of having better access to goods and services of greater monetary value that ultimately leads to an affordable and healthier lifestyle.

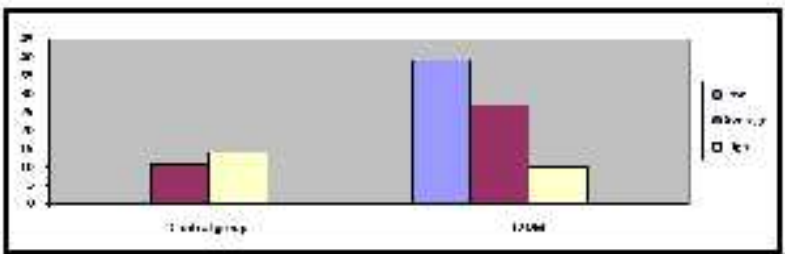

Figure I Socioeconomic status of control group participants and T2DM[N.B: Poor Low- Upto Rs5000/- per month, Average- Above Rs5000/- to below Rs20000/- per month, Good- Above Rs20000/- per month.]

Comparisons between Control and T2DM cases in terms of Glucose concentration following Impaired Fasting Glucose and Oral Glucose Tolerance Test have been graphically presented in Figure IIa and IIb respectively.

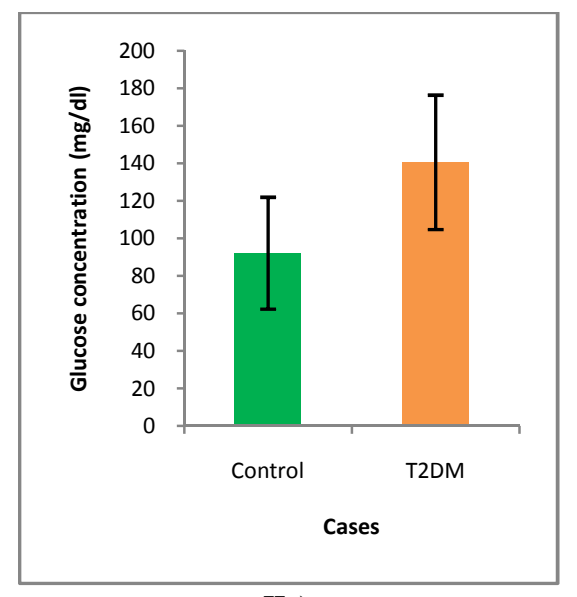

IIa)
Comparison between Control and T2DM cases in terms of HbAIC (\%) has been presented graphically in Figure III.

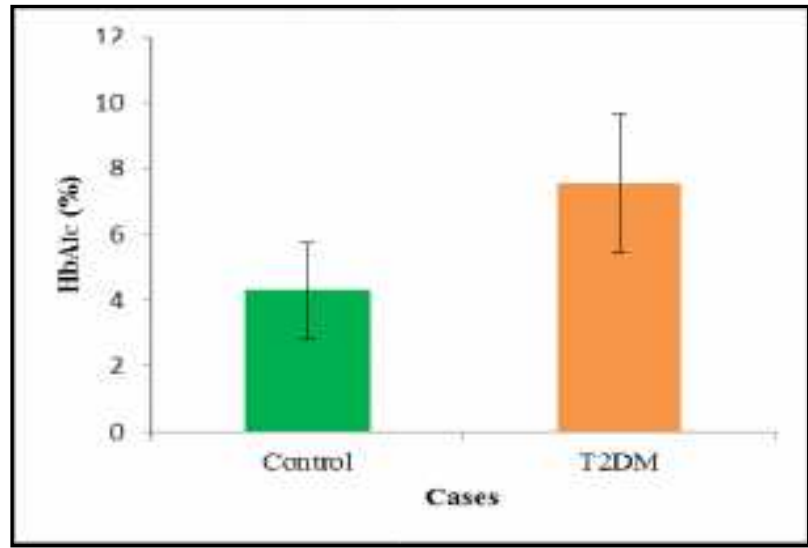

Figure III Comparison between Control and T2DM cases in terms of $\mathrm{HbAIC} \mathrm{( \% )}$

In the present study, analysis of DNA damage in exfoliated buccal cells of patients with T2DM and the control participants were evaluated by micronuclei assay. The prepared slides were screened by blind analysis under compound light microscope (Olympus, Model No.CH20Itr), 100x magnification oil immersion lens and according to the The Fenech criteria:

(a) a diameter between $1 / 16$ and $1 / 3$ of the mean diameter of the main nucleus; (b) non-refractivity; (c) no linkage or connection to or overlap with the main nucleus; (d) the same staining intensity as the nucleus; and (d) location within the cytoplasm, the MN were identified.

Table II Presence of MN in case and control group participants

\begin{tabular}{cccc}
\hline Micronuclei & Controls & \multicolumn{2}{c}{$\begin{array}{c}\text { T2DM } \\
\text { patients }\end{array}$} \\
\hline Present & $7(28 \%)$ & $69(90 \%)$ \\
Absent & $18(72 \%)$ & $7(10 \%)$ \\
\hline
\end{tabular}

Table III Comparison of MN frequency between case and control group

\begin{tabular}{ccc}
\hline Study group & Controls & T2DM patients \\
\hline $\mathrm{N}$ & 25 & 76 \\
No. Of cells studied & 25,000 & 76,000 \\
Micronuclei & $1.1 \pm 0.9$ & $4.29 \pm 3.72$ \\
frequency(Mean \pm SD) & & \\
\hline
\end{tabular}

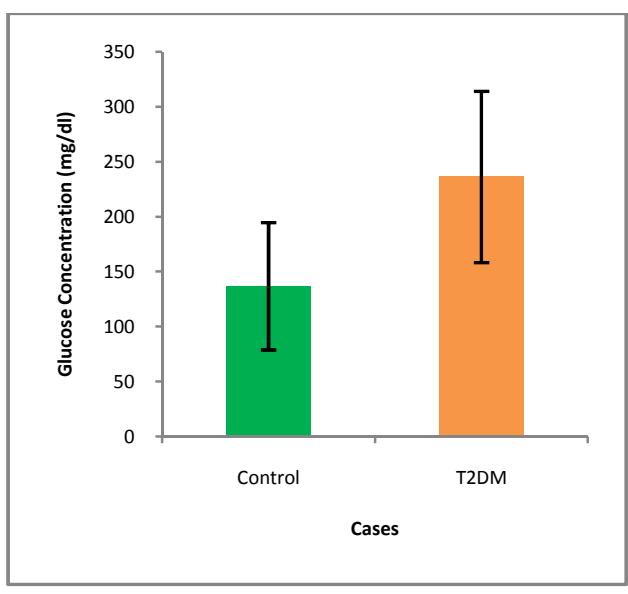

IIb)

Figure II Comparison between Control and T2DM cases in terms of Glucose concentration following Impaired Fasting Glucose and Oral Glucose Tolerance Test 
Table II summarises that the maximum percentage of MN were observed in the patients with T2DM $(90 \%)$ than control group (28\%).

An increased MN frequency was observed in the diabetic group than the healthy controls in Table III. In the present study, frequency of $\mathrm{MN}$, found in T2DM patients, was 4.08 \pm 3.77 which was much higher than the control group participants $(1.1 \pm 0.9)$.

Table IV Distribution of MN frequency in T2DM patients according to duration of diabetes.

\begin{tabular}{ccc}
\hline $\begin{array}{c}\text { Duration } \\
\text { of } \\
\text { T2DM }\end{array}$ & $\begin{array}{c}\text { Total no. } \\
\text { Of cases }\end{array}$ & $\begin{array}{c}\text { Frequency of Micronuclei } \\
\text { in T2DM patients } \\
\text { ( Mean } \pm \text { SD) }\end{array}$ \\
\hline <5yrs & $\mathrm{n}=19$ & $1.47 \pm 1.13$ \\
$5-10 \mathrm{yrs}$ & $\mathrm{n}=33$ & $2.91 \pm 0.9$ \\
$>10 \mathrm{yrs}$ & $\mathrm{n}=24$ & $8.1 \pm 4.7$ \\
\hline
\end{tabular}

Table IV illustrated the distribution of MN frequency in T2DM patients according to the duration of diabetes. The frequency of $\mathrm{MN}$ was maximum in patients having T2DM more than 10 years $(8.1 \pm 4.7)$ as compared to patients of $5-10$ years duration $(2.91 \pm 0.9)$ and patients with T2DM for less than 10 years $(1.47 \pm 1.13)$. predict the occurrence of complications in diabetes mellitus [11]. The study revealed that the frequency of $\mathrm{MN}$ was significantly increased in patients with T2DM relative to controls. Preliminary results show elevated levels of DNA damage in these patients $(4.08 \pm 3.77)$ compared to controls $(1.1 \pm 0.9)$. The high frequency of $\mathrm{MN}$ observed in patients with T2DM may be due to an elevated level of OS that leads to a decrease in glutathione synthesis, because the accumulated products of OS, especially ROS, can cause DNA damage [28].This is consistent with a study done by MartínezPérez L. M et al[16]. The levels of buccal MN in diabetic individuals are approximately 2-fold higher than in nondiabetic participants, as revealed by Elisabeth mullner et al [18]. Zuniga-Gonzalez et al stated that the increased frequency of MN levels in exfoliated buccal cells in type 1 and type 2 diabetic patients compared with control group [21]. Thus these findings support our study. The frequency of MN was more in patients having T2DM for more than 10 years. But in case of patients of duration less than 5 years, the frequency of MN sloped down. This may be due to the fact that increased duration of T2DM enhances the risk of progression of late diabetic complications. MN identified in exfoliated buccal cells enhances genetic damage.
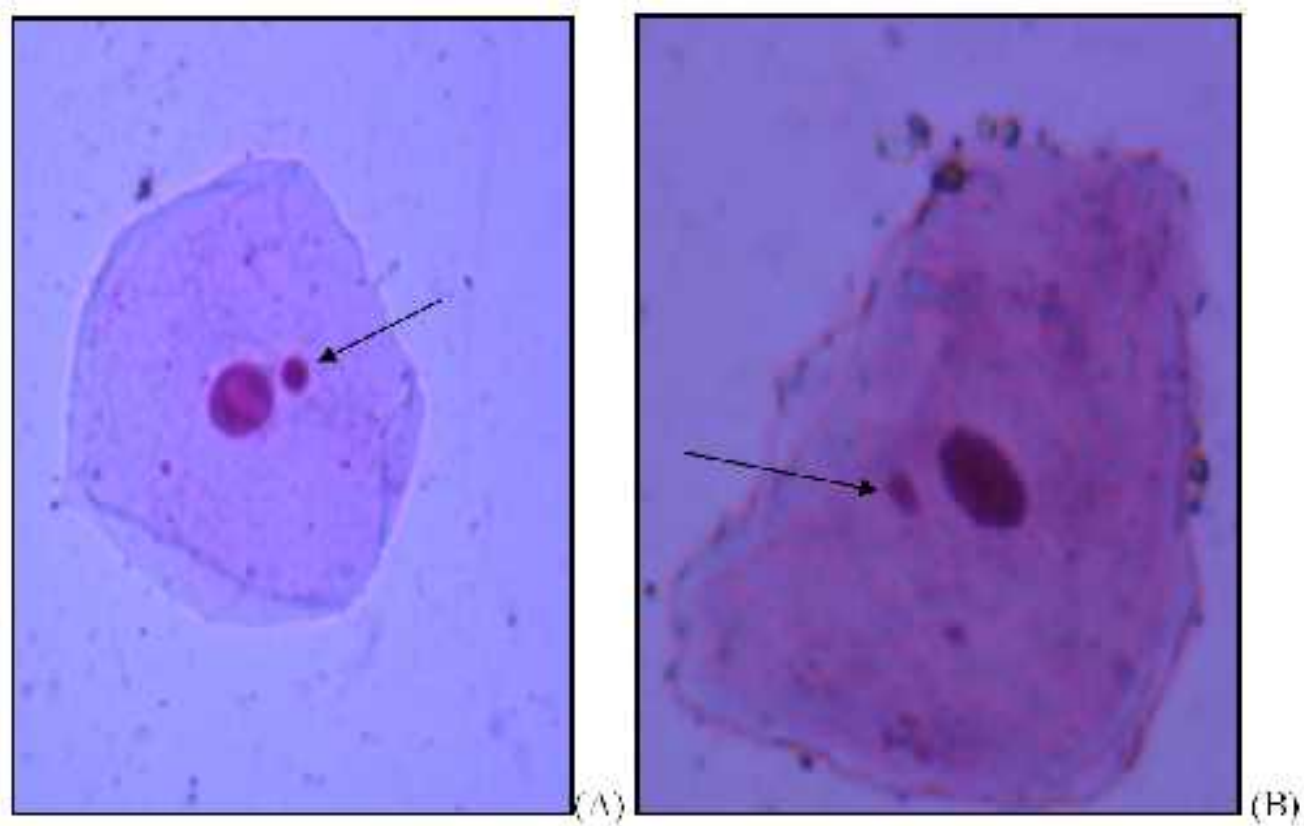

Fig IV(A) \& (B) Micronucleus in exfoliated buccal cells of patients with T2DM

\section{DISCUSSION}

T2DM is associated with OS that leads to protein, lipid and DNA modifications causing cellular dysfunction. The overproduction of ROS can cause oxidative damage to a large number of molecules, including DNA and that contributes to the pathological processes of late diabetic complications [26]. The presence of an increased OS in diabetic patients is a well established fact. This can enhance the teratogenic or carcinogenic consequences [27]. There are increasing evidences obtained from both experimental and clinical studies suggesting that a close association has been found among hyperglycemia, OS and diabetic complications.

In the present study, frequency of $\mathrm{MN}$ in exfoliated buccal cells were observed in both T2DM patients and control participants as $\mathrm{MN}$ index can be used as a biomarker to
Our finding support an increase in the frequency of cells with damaged chromosomes in T2DM patients. The increase in the frequency of cells with $\mathrm{MN}$ in patients with T2DM can contribute to genomic instability, and consequently to cancer [29]. Martinez-Pérez L et al., illustrated that T2DM patients have significantly more genetic damage (in terms of $\mathrm{MN}$ frequency) than nondiabetics. This indicates that $\mathrm{MN}$ may be a useful constituent in a panel of biomarkers for the risk of late diabetic complications, mostly cancer [16]. Assessment of micronuclei (MN) in exfoliated buccal cells, might be of high relevance in future as up to $90 \%$ of all cancers are of epithelial origin, as stated by Cairns [30]. Several epidemiologic studies reported higher significant risk of cancer in diabetic patients and were $20 \%$ more in diabetic patients [31, 32]. 


\section{CONCLUSION}

MN were observed in increased frequency in type 2 diabetes mellitus patients. This investigation may be considered as preliminary study of DNA damage in T2DM because the effects of the potential confounders are not properly delineated in such cases. Further studies should be done for interaction between these factors with large number of sample population. However, our study illustrated that T2DM have more genetic damage due to elevated frequency of MN. This depicts that demonstration of $\mathrm{MN}$ can be a useful biomarker for the risk of late diabetic complications and a predisposing factor for development of cancer.

\section{Acknowledgments}

We would like to acknowledge our Secretary, Ramakrishna Mission Seva Pratishthan, colleagues of our department and all the patients who participated in this study.

\section{Author Statements}

Ethical approval: This study was approved by the institutional ethical committee on $10^{\text {th }}$ May, 2016. Reg No. ECR/62/Inst/WB/2013 issued under Rule 122DD of the Drugs \& Cosmetics Rules 1945.

\section{References}

1. Brussels. 2011. Global burden of diabetes. International Diabetes federation, in: Diabetic atlas. 5th ed, http://www.idf.org/diabetesatlas/ (accessed 18th December 2011).

2. Zimmet, P., Alberti, K.G. and Shaw, J. 2001. Global and societal implications of the diabetes epidemic. Nature., 414:782-787.

3. Chamnan, P., Simmons, R.K., Forouhi, N.G., Luben, R., Khaw, Ky., Wareham, N.J. et al. 2011. Incidence of type 2 diabetes using proposed HbA1c diagnostic criteria in the EPIC-Norflok cohort: Implication for preventive strategies, http://care.diabetesjournal.org./ (accessed 19th December 2011).

4. Wild., Sarah., Gojka, Roglic., Anders, Green., Richard, Sicree. and Hilary, King. 2004. Global Prevalance of Diabetes. American Diabetes Association. Diabetes Car., 27(5): 1047-1053.

5. Sicree, R., Shaw, J. and Zimmet, P. 2006. International Diabetes Federation., pp.16-103.

6. Joshi, A.R., Pranita, A. and Phadke, A.V. 2012. Diabesity: curse of development. Int J Med., 12:77-78.

7. Shashank, R.J., Banshi, S., Muruga, V. et al. 2012. Prevalence of diagnosed and undiagnosed diabetes and hypertension in India-results from the Screening India's Twin Epidemic (SITE) study. Diabetes Technol Ther., 12(1):8-15. doi:10.1089/dia.2011.0243. [PubMed] [Cross Ref]

8. Brownlee M.1994. Glycation and diabetic complications. Diabetes., 43:836-841.

9. Singh, R., Barden, A., Mori, T. And Beilin, L. 2001. Advanced glycation end-products: a review. Diabetologia., 44:129-146.

10. Mohanty, P., Hamouda, W., Garg, R., Aljada, A., Ghanim, H. and Dandona P. 2000. Glucose challenge stimulates reactive oxygen species (ROS) generation by leucocytes. J. Clin. Endocrinol. Metab., 85: 29702973.
11. Shettigar, S.K., Shailaja, C. and Kulkarni, R.K. 2012. Elevated micronuclei frequency in type 2 diabetes with high glycosylated hemoglobin. Diabetes Res. Clin. Pract., 95: 246-250.

12. Mantena, R.K.R., Wijburg, O.L.C., Vindurampulle, C., Bennett-Wood, V.R., Walduck, A., Drummond, G.R., Davies, J.K., Robins-Browne, R.M. and Strugnell. 2008. RA.Reactive oxygen species are the major antibacterials against Salmonella Typhimurium purine auxotrophs in the phagosome of RAW 264.7 cells. Cell. Microbiol., 10 (5): 1058-1073.

13. Will, J.C., Galuska, D.A., Vinicor, F. and Calle, E.E. 1998. Colorectal cancer: another complication of diabetes mellitus? Am J Epidemiol., 147(9):816-25.

14. Maisonneuve, P., Agodoa. L., Gellert, R., Stewart, J.H., Buccianti, G., Lowenfels, AB. et al. 1999. Cancer in patients on dialysis for end-stage renal disease: an international collaborative study. Lancet., 354(9173):93-9.

15. Bolognesi, C., Knasmueller, S., Nersesyan, A., Thomas, P. and Fenech, M. 2013. The HUMNxl scoring criteria for different cell types and nuclear anomalies in the buccal micronucleus cytome assayAn update and expanded photogallery. Mutation Research., 753:100-113.

16. Martínez-Pérez, L.M., Cerda-Flores, R.M.C., Gallegos, Cabriales, E.C., Dávila-Rodríguez, M., Ibarra-Costilla, E. and Cortés-Gutiérrez, E.I. 2007. Frequency of Micronuclei in Mexicans with Type 2 Diabetes Mellitus. Prague Medical Report.,108 (3):248-255.

17. Fenech, M., Kirsch-Volders, M., Natarajan, A., Surralles, J., Crott, J., Parry, J. et al. 2011. Molecular mechanisms of micronucleus, nucleoplasmic bridge and nuclear bud formation in mammalian and human cells. Mutagenesis.,26:125-132.

18. Elisabeth, Mullner., Helmut, Brath., Armen, Nersesyan., Marlies, Nitz. et al. 2013. Nuclear anomalies in exfoliated buccal cells in healthy and diabetic individuals and the impact of a dietary intervention. Mutagenesis.,29 (1):1-6.

19. Shen, Z. 2011. Genomic instability and cancer: an introduction. J. Mol. Cell Biol.,3:1-3.

20. Thomas, P., Holland, N., Bolognesi, C., KirschVolders, M., Bonassi, S., Zeiger, E., Knasmueller, S. and Fenech, M. 2009. Buccal micronucleus cytome assay. Nat. Protoc.,4:825-837.

21. Zuniga-Gonzalez, G.M., Batista-Gonzalez, C.M., Gomez-Meda, B.C., Ramos-Ibarra, M.L., ZamoraPerez, A.L., Munoz-Magallanes, T., Ramos, Valdes, C. and Gallegos-Arreola, M.P. 2007. Micronuclei in diabetes: folate supplementation diminishes micronuclei in diabetic patients but not in an animal model. Mutat. Res., 634:126-134.

22. Tolbert, P.E., Shy, C.M. and Allen, J.W. 1991. Micronuclei and other nuclear anomalies in buccal smears: a field test in snuff users. Am J epidemiol., 134:840-850.

23. Robbins, J., Vaccarino, V., Zhang, H. and Kasl, S. 2001. Socioeconomic status and type 2 diabetes in African American and Non-Hispanic white women and men: Evidence from the Third National Health and Nutrition Examination Survey. American Journal of Public Health., 91:76-84. 
24. National Public Health Survey. 1998. Statistics Canada.

25. Stelmach, W., Kaczmarczyk-Chalas, K., Bielecki, W. and Drygas, W. 2005. How education, income, control over life and lifestyle contribute to cardiovascular risk factors in adults in a post-communist country. Public Health., 119:498-508. doi:10.1016/j.puhe.2004.09.006.

26. Mehrotra, S., Ling, K.L., Bekele, Y. et al. 2001. Lipid hydroperoxide and markers of renal disease susceptibility in African-Caribbean and Caucasian patients with Type 2 diabetes mellitus. Diabet Med., 18(2): 109-115.

27. Jee, S., Ohrr, H., Yun, J. et al. 2005. Fasting serum glucose level and cancer risk in Korean men and women. JAMA., 293(2):194-202.
28. Blasiak, J., Arabski, M., Krupa, R., Wozniak, M.Z., Ka, Sznicki, J., Zurawska, M. and Drzewoski, J. 2004. DNA damage and repair in type 2 diabetes mellitus. Mutat. Res., 554:297 -304.

29. Fenech, M. 2002. Chromosomal biomarkers of genomic instability relevant to cancer. Drug Discov., 7:1128-1137.

30. Cairns, J. 1975. Mutation selection and the natural history of cancer. Nature., 255:197-200.

31. Zendehdel, K., Nyren, O., Ostenson, C.G. et al. 2003. Cancer in patients with type 1 diabetes mellitus: a population-based cohort study in Sweden. J Natl Cancer Inst., 95:1797-800.

32. Collins, A., Cadet, J., Moller, L. et al. 2004. Are we sure we know how to measure 8-oxo-7, 8dihydroguanine in DNA from human cells? Arch Biochem Biophys., 423:57-65.

\section{Please cite this article in press as:}

Priyanka Biswas., Neepa Banerjee., Prasanta Bhattacharya., Aniket Adhikari., Shankarashis Mukherjee and Madhusnata De (2017), Micronuclei In Exfoliated Buccal Cells: A Biomarker For Dna Damage Leading To Progression Of Late Diabetic Complications In Type 2 Diabetes Mellitus Patients', International Journal of Current Advanced Research, 6(3), pp. 23662371. http://dx.doi.org/10.24327/ijcar.2017. 2371.0011 